QUALITY

Volume 8, Nomor 2, 2020, 359-376

\title{
Implementasi Manajemen Madrasah Unggul Berbasis Kurikulum Pesantren MI Qudsiyyah Kudus
}

\author{
Sutrisno \\ MI Qudsiyyah, Kudus, Indonesia \\ einsutrisna@gmail.com
}

\begin{abstract}
Abstrak
Implementasi Manajemen Madrasah Unggul Berbasis Kurikulum Pesantren MI Qudsiyyah Kudus, Penelitian ini bertujuan untuk memberikan gambaran tentang penerapan manajemen madrasah berbasis kurikulum pesantren meliputi perencanaan, strategi pengembangan, implementasi dan evaluasi pengelolaan di MI Qudsiyyah Kudus. Metode penelitian ini menggunakan metode kualitatif deskriptif dengan penjabaran seluruh aspek penerapan manajemen madrasah unggul berbasis kurikulum pesantren di MI Qudsiyyah Kudus. Hasil penelitian menunjukkan: 1) Perencanaan berupa penelaahan tujuan, konten kurikulum melalui pendekatan mata pelajaran dan pendekatan proses, kegiatan, sumber yang digunakan dan instrumen pengukuran, 2) Strategi pengembangan yang diterapkan meliputi membangun kekuatan internal madrasah, memperkuat kepemimpinan, membangun pencitraan madrasah, progam unggulan, membangun kepedulian sosial; 3) Pelaksanaan kurikulum integrasi di MI Qudsiyyah memprioritaskan sisi unggulan meliputi input terseleksi ketat, guru profesional serta siswa berprestasi, inovasi kurikulum, kontributif di tengah masyarakat, 4) Evaluasi manajemen dilaksanakan dengan model evaluasi bulanan dan evaluasi tahunan dengan tahapan; menganalisis progam yang sudah ada, pemantauan dan pengawasan dan membuat laporan tertulis.
\end{abstract}

Kata Kunci: Manajemen Madrasah; Madrasah Unggul; Kurikulum Pesantren 


\begin{abstract}
Implementation of Superior Madrasah Management Based on the MI Qudsiyyah Kudus Pesantren Curriculum. This study aims to provide an overview of the implementation of Islamic boarding school curriculumbased madrasah management including planning, development strategies, implementation and management evaluation at MI Qudsiyyah Kudus. This research method uses descriptive qualitative method with the elaboration of all aspects of the implementation of superior madrasah management based on the pesantren curriculum at MI Qudsiyyah Kudus. The results showed: 1) Planning in the form of a study of objectives, curriculum content through a subject approach and a process approach, activities, resources used and measurement instruments, 2) The development strategy applied includes building internal strength of madrasah, strengthening leadership, building madrasah image, program superiority, building social awareness; 3) Implementation of the integrated curriculum at MI Qudsiyyah prioritizes superiority including tightly selected input, professional teachers and outstanding students, curriculum innovation, contributive in the community, 4) Management evaluation is carried out with a monthly evaluation model and an annual evaluation with stages; analyze existing programs, monitor and supervise and produce written reports.
\end{abstract}

Keywords: Madrasah Management; Superior Madrasah; Pesantren Curriculum

\title{
A. Pendahuluan
}

Madrasah Unggul adalah sebuah madrasah program unggulan yang lahir dari sebuah keinginan untuk memiliki madrasah yang mampu berprestasi di tingkat nasional dan dunia, dalam penguasaan ilmu pengetahuan, keterampilan dan teknologi yang ditunjang oleh akhlakul karimah. Untuk mencapai keunggulan tersebut, maka masukan (input), proses pendidikan, guru dan tenaga kependidikan, manajemen, layanan pendidikan, serta sarana penunjangnya harus diarahkan untuk menunjang tercapainya tujuan tersebut (Ahmad Zayadi, 2005:57). Dengan pengertian tersebut, madrasah unggulan perlu ditunjang dengan tenaga pendidik yang perofesional, saran yang memadai, kurikulum yang inovatif, ruang kelas atau pembelajaran yang representatif sehingga dapat mendorong terciptanya pembelajaran yang efektif dan efisien dan menghasilkan lulusan yang berkualitas. Menurut Bafadhal berpendapat bahwa untuk mencapai madrasah yang unggul 


\section{Sutrisno}

dituntut adanya fasilitas dan dana yang memadai, akan tetapi tidak semua sekolah atau madrasah dapat memenuhinya. Secara teknis, pengembangan madrasah unggulan menuntut adanya tenaga yang profesional dan fasilitas yang memadai sehingga dampaknya membutuhkan biaya belajar yang tidak sedikit (Bafadal, 2006:86).

Berdasarkan visi dan misi madrasah unggulan, maka dapat ditentukan tujuan dari madrasah unggulan yaitu membentuk individu yang profesional dan religius. Secara umum tujuan dari madrasah unggulan sendiri adalah pandangan atau acuan bersamaseluruh komponen madrasah akan keadaan masa depan yang diinginkan dan diungkapkan dengan kalimat yang jelas, positif, menantang dan mengundang partisipasi untuk gambaran pendidikan masa depan (Qomar, 2007:28). Keunggulan madrasah di Kudus saat ini terletak pada tiga jenis, yaitu keunggulan madrasah berbasis Tafaqquh Fiddin (berbasis Kurikulum Pesantren, Madrasah berbasis Tahfidz dan Madrasah berbasis Riset (Kisbiyanto \& Setyoningsih, 2016:120).

Undang-undang nomor 20 tahun 2003 menyebutkan bahwa kurikulum adalah seperangkat rencana dan pengaturan mengenai tujuan, isi, dan bahan pelajaran serta cara yang digunakan sebagai pedoman penyelenggaraan kegiatan pembelajaran untuk mencapai tujuan pendidikan tertentu. Sudjana (2008: 21) mengemukakan empat macam komponen-komponen pembentuk kurikulum yang berupa tujuan kurikulum, isi dan struktur kurikulum, strategi pelaksanaan kurikulum, evaluasi kurikulum.

Pesantren adalah sekolah tradisional Islam berasrama di Indonesia. Institusi pengajaran ini memfokuskan pada pengajaran agama dengan menggunakan metode pengajaran tradisional dan mempunyai aturan administrasi dan kurikulum pengajaran yang khas. Dalam sejarah awalnya, pesantren kurang mengenal istilah kurikulum, tapi kalangan pesantren pada waktu itu lebih mengenal dengan istilah materi pelajaran, kitab-kitab yang diajarakan atau ilmu-ilmu yang dipelajari. Dalam kontek itu semua, karena pesantren dianggap sebagai kelanjutan dari langgar di 


\section{Sutrisno}

Jawa, maka yang diajarkan mula-mula adalah ilmu Sharaf, Nahwu, Kemudian ilmu Fiqih, Tafsir, Ilmu Tauhid, dan akhirnya sampai kepada ilmu Tasawuf dan lain sebagainya. Pendek kata ilmu yang diajarkan di pesantren adalah ilmu-ilmu Bahasa Arab (pasif) dan ilmu-ilmu agama Islam (Zuhri, 2016: 193-194).

Saat ini perkembangan pendidikan pesantren ada yang bertransformasi menjadi madrasah, hal ini merupakan buah dari pergeseran tuntutan masyarakat yang tidak mau melepaskan dirinya dari model Pendidikan Pesantren, sementara disisi lain mereka juga tidak mau kehilangan kesempatan untuk terlibat dalam tuntutan dinamika masyarakat baru. Pilihannya adalah mereka tetap berada dalam ruang pola pendidikan tradisional yakni pendidikan pesantren, tapi mereka juga dapat menginjakkan kaki yang satunya lagi pada pola pendidikan modern sekolah (Muhtadi, 2014:15). Tentu dengan pernyataan tersebut saat ini masyarakat menginginkan terciptanya suatu lembaga pendidikan formal yang kurikulumnya terpadukan dengan kurikulum pondok pesantren dengan ciri khasnya mempelajari dan mendalami khazanah keilmuan Islam (Al-Ulum As-Salafiyyah). Sehubungan dengan pernyataan di atas MI Qudsiyyah Kudus hadir dengan tawaran solusi penerapan kurikulum integratif. Langkah yang ditempuh antara lain untuk menambah muatan-muatan keilmuan pesantren dan menambah jam pembelajaran muatan lokal salaf sehingga memungkinkan proses penguatan dan pengayaaan materi kurikuler sesuai standar visi misi madrasah. Kualitas madrasah tersebut tergolong baik, dibuktikan dengan perolehan predikat A berturut-turut pada rangkaian akreditasi lembaga dan berbagai prestasi siswa dalam berbagai kompetisi dan secara kuantitas jumlah siswa Madrasah Ibtidaiyyah Qudsiyyah pada tahun 2020 ini mencapai 1.044 siswa terbagi dalam 29 lokal kelas yang berasal dari seluruh penjuru wilayah Indonesia.

Berdasar pemaparan tersebut di atas, peneliti sebagai akademisi terdorong untuk menelaah fenomena penyelenggaraan pendidikan berbasis kurikulum pesantren di MI Qudsiyyah Kudus. Jenis penelitian yang peneliti lakukan yaitu deskriptif kualitatif. Penelitian deskriptif kualitatif adalah pendekatan yang 
mengutamakan pengumpulan data atau kebenaran masalah dengan berasaskan pada penemuan informasi-informasi yang telah dilaksanakan dan diungkapkan oleh informan, serta data yang diperoleh dalam bentuk kata-kata dan bahasa oleh individu-individu dan perilaku yang diamati (Moleong, 2009: 3). Penelitian ini menggunakan pendekatan penelitian kualitatif dan tergolong ke dalam jenis penelitian lapangan (field research). Objek kajian penelitian ini adalah manajemen pengembangan madrasah unggul berbasis kurikulum pesantren. Adapun subjeknya terdiri dari kepala sekolah, waka kurikulum, waka kesiswaan, waka humas, waka sarpras, dan siswa. Penggalian data dilakukan pada tahun ajaran 2020/2021 dengan teknik wawancara, observasi, dan dokumentasi.

Pengecekan keabsahan data dilakukan dengan cara perpanjangan pengamatan, meningkatkan ketekunan dan triangulasi yang meliputi triangulasi sumber dan teknik. Sementara itu, data dianalisis dengan model analisis interaktif Miles dan Huberman yang dimulai dengan reduksi data, display data, hingga penarikan kesimpulan (conclusion drawing).

\section{B. Pembahasan}

\section{Perencanaan Manajemen Madrasah Unggul Berbasis Kurikulum Pesantren di MI Qudsiyyah Kudus}

Pengembangan madrasah unggulan menuntut adanya tenaga yang profesional dan fasilitas yang memadai (Ibrahim Bafadal,2006:86). Madrasah Unggulan adalah sebuah madrasah program unggulan yang lahir dari sebuah keinginan untuk memiliki madrasah yang mampu berprestasi di tingkat nasional dan dunia, dalam penguasaan ilmu pengetahuan, keterampilan dan teknologi yang ditunjang oleh akhlakul karimah. Untuk mencapai keunggulan tersebut, maka masukan (input), proses pendidikan, guru dan tenaga kependidikan, manajemen, layanan pendidikan, serta sarana penunjangnya harus diarahkan untuk menunjang tercapainya tujuan tersebut (Zayadi, 2005: 57).

Perencanaan kurikulum berbasis pesantren di MI Qudsiyyah Kudus dilaksanakan oleh seluruh elemen madrasah meliputi kepala madrasah, waka 


\section{Sutrisno}

bidang kurikulum, waka bidang sarpras, waka bidang humas, waka bidang kesiswaan, kepala TU dan pengurus komite madrasah. Pokok inti dari proses perencanaan kurikulum berbasis pesantren di MI Qudsiyyah ialah menetapkan point-point penting sebagai dasar rancangan rancangan kurikulum meliputi penelaahan tujuan, konten kurikulum melalui pendekatan mata pelajaran dan pendekatan proses, kegiatan (aktivitas), sumber yang digunakan dan instrumen evaluasi (pengukuran).

Adapun secara rinci komponen dalam rancangan perencanaan kurikulum di MI Qudsiyyah Kudus adalah sebagai beikut:

a) Menetapkan Tujuan Pengajaran

Tujuan kurikulum berbasis kurikulum pesantren di MI Qudsiyyah ialah untuk pelestarian keilmuan agama dengan corak kesalafan-nya kepada semua masyarakat. Karena dengan pendidikan agama model pesantren inilah secara intens penanaman nilai-nilai ketuhanan serta karakter kemanusiaan diajarkan di dalamnya.

Kemudian dalam penetapan tujuan kurikulum tersebut dijabarkan melalui penyusunan visi ,misi, tujuan dan target lembaga pendidikan MI Qudsiyyah Kudus.

b) Menetapkan Materi Pembelajaran

Materi pembelajaran merupakan isi dari suatu kurikulum, yakni berbentuk mata pelajaran atau bidang studi dengan topik, sub topik dan rincian penjelasannya. Maksud dari pelaksanaan pembelajaran tampak dalam materi pembelajaran yang disampaikan kepada siswa sebagai esensi dari apa yang akan disampaikan dalam pelaksanaan pembelajaran. Tanpa materi pembelajaran, pelaksanaan pembelajaran tidak akan berjalan dengan baik (Jamarah, 2006: 43).

Materi-materi pembelajaran yang diajarkan di MI Qudsiyyah Kudus merupakan materi pembelajaran terpadu antara materi ajar basis kurikulum pesantren dengan materi ajar basis Kurikulum Nasional yang diajarkan di MI Qudsiyyah Kudus. 


\section{Sutrisno}

c) Model Evaluasi Pembelajaran

Evaluasi atau penilaian digunakan untuk menentukan apakah tujuan pembelajaran dapat tercapai atau tidak. Evaluasi mempunyai tujuan untuk mengetahui tingkat kemampuan siswa, perkembangan masing-masing siswa, untuk mengetahui kekurangan dan kelemahannya, dan untuk mengetahui apakah pembelajaran yang dilaksanakan guru dapat berjalan dengan sukses atau tidak. Oleh karena itu evaluasi perlu direncanakan secara rinci sebelum pembelajaran dilaksanakan. Tahap perencanaan evaluasi ini meliputi penentuan tujuan evaluasi, menentukan alat evaluasi, dan menyusun instrumen evaluasi (Purwanto, 2004: 7).

Model evaluasi pembelajaran di MI Qudsiyyah Kudus menerapkan dua model evaluasi, yaitu evaluasi berbentuk tes dan non tes. Untuk Evaluasi Model Tes di MI Qudsiyyah menggunakan model tes sumatif dan tes formatif. Tes sumatif berupa penilaian tengah semester ataupun akhir semester. Adapun tes formatif biasanya berupa penilaian harian, bisa berupa tes tertulis ataupun tes lisan (berupa hafalan atau sorogan kitab salaf).

\section{Strategi Manajemen Madrasah Unggul Berbasis Kurikulum Pesantren di MI Qudsiyyah Kudus}

Strategi manajemen untuk mengembangkan madrasah unggul sebagai berikut (Muhaimin, 2009: 105):

a. Membangun berbagai kekuatan di madrasah yang meliputi: memiliki guru yang mempunyai kompetensi, dedikasi dan komitmen yang tinggi, memiliki siswa yang berprestasi, memiliki budaya madrasah yang kokoh, memiliki seorang panutan di madrasah, memiliki motivasi yang tinggi untuk mampu bersaing dan menciptakan kebersamaan yang erat dari berbagai komponen yang ada di dalam komunitas madrasah.

Perekrutan guru Pengurus YAPIQ yang menaungi lembaga pendidikan MI Qudsiyyah merekrut guru melalui beberapa persyaratan yang harus dipenuhi. Persyaratan tersebut meliputi: 
(1) Penetapan sebagai guru harus berasal dari alumni Madrasah Qudsiyyah sendiri.

(2) Kualifikasi latar belakang pendidikan calon guru harus sesuai dengan tugas pengajaran di madrasah. Apabila kebutuhan guru diperentukkan sebagai pengajar mata pelajaran salaf maka personil calon guru yang diterima adalah para alumni pondok pesantren salaf dan jika untuk pengajaran mata pelajaran umum maka yang diterima adalah alumni perguruan tinggi yang linier.

(3) Tes Interview dengan ketua yayasan beserta wakilnya dan kepala madrasah secara langsung.

Kemudian untuk siswa lulusan MI/MTs dari luar Qudsiyyah yang ingin bersekolah di Madrasah Qudsiyyah harus memenuhi syarat-syarat khusus sesuai standar kompetansi atau kemampuan sebagaimana lulusan MI/MTS Qudsiyyah melalui tes tertulis dan lisan. Kemudian baru pada tahun pelajaran 2008/2009 MTs Qudsiyyah bisa menerima lulusan MI langsung masuk ke MTs, meskipun dengan syarat ada penambahan jam belajar pada siang hari untuk mengejar kekurangan pengetahuan agama.

b. Memperkuat kepemimpinan dan manajemen madrasah.

Khusus dalam perekrutan kepala madrasah baru di Madrasah Qudsiyyah, pihak yayasan (YAPIQ) merekrut guru senior yang mempunyai kompetensi unggul sebagai kepala madrasah. Dengan demikian sistem kepemimpinan dan manajemen madrasah dapat berjalan dengan baik mengingat pimpinan yang ditetapkan merupakan pribadi yang berwibawa dan mumpuni.

c. Membangun pencitraan madrasah.

MI Qudsiyyah Kudus dalam mempublikasi segala bentuk kegiatan baik akademik maupun non akademik seperti peringatan hari besar Islam dan momenmomen acara lainnya dituangkan dalam website madarasah, yaitu www.Qudsiyyah.com. Hal ini sebagai upaya perluasan jangkauan publikasi skala nasional maupun internasional. Sehingga siapapun dan dimanapun dapat menggali informasi tentang Madrasah Qudsiyyah dengan mudah dan praktis. 
d. Mengembangkan program-program unggulan.

Madrasah Qudsiyyah merintis perkembangannya dengan progam tahfidz di Ma'had Qudsiyyah yang dipadukan dengan corak khas karakter madrasah sejak dulu yaitu pendalaman kitab-kitab kuning. Namun untuk progam tahfidz masih dikhususkan pada siswa Qudsiyyah yang nyatri di ma'had saja, adapun siswa yang tidak nyantri di ma'had hanya di wajibkan menghafalkan surat-surat tertentu dari Al-Qur'an dan pelajaran-pelajaran kitab salaf.

Disamping progam tahfidz dan pendalaman kitab kuning di Madrasah Qudsiyyah juga mengembangkan perpustakaan digital dengan puluhan ribu judul buku dan kitab telah tersedia dengan rapi di dalam shoftware Maktabah AsSyamilah. Hal ini memberikan kemudahan bagi seluruh guru maupun siswa dalam berliterasi kitab-kitab yang diperlukan dalam bahtsul masail maupun kegiatan media pengayaan literasi belajar mandiri.

e. Harus berani mengubah mindset atau cara berfikir umat Islam, untuk lebih peduli terhadap kepentingan sosial dan tidak terjebak ke dalam hedonisme spiritual, yakni ahli ibadah yang hanya memberikan manfaat kepada dirinya saja, bukan memberikan manfaat kepada orang lain.

Langkah MI Qudsiyyah Kudus menjalin hubungan harmonis dengan lingkungan madrasah merupakan suatu upaya kontrol sosial yang dibangun oleh pihak madrasah. Setiap hari raya Idul Adha MI Qudsiyyah Kudus selalu mengadakan kegiatan Bakti Sosial di daerah-daerah yang tingkat sosial keagamaannya kurang. Disamping itu juga mengadakan agenda silaturrahim Halal Bihalal kepada masyarakat sekitar madrasah pada hari raya Idul Fitri.

f. Perlunya pengembangan pendidikan di madrasah dengan menerapkan empat strategi, yaitu, Pertama, strategi substantif, yakni lembaga pendidikan perlu menyajikan program-program yang komprehensif. Kedua, strategi buttomup, yakni lembaga pendidikan harus tumbuh dan berkembang dari bawah. Ketiga, strategi deregulatory, yakni lembaga pendidikan sedapat mungkin 
tidak terikat pada ketentuan-ketentuan baku yang terlalu sentralistik dan mengikat, pendidikan yang out of the box. Keempat, strategi cooperative, yakni lembaga pendidikan perlu mengembangkan jaringan kerja sama, baik sesama lembaga pendidikan yang setingkat atau dengan yang lainnya pada tingkat regional, nasional maupun internasional.

Secara subtansif perkembangan MI Qudsiyyah Kudus cukup signifikan dengan ciri khas pendidikan Agama Islam berbasis salaf, kurikulum yang diajarkan pada madrasah tersebut $75 \%$ berbasis salaf (pesantren) dengan menggunakan kitab klasik atau yang biasa disebut dengan istilah kitab kuning.

Kemudian sebagai langkah pengembangan dengan pendekatan strategi buttom-up, Pengurus Yayasan Pendidikan Islam Qudsiyyah pada tahun 2012 mendirikan Ma'had Qudsiyyah sebagai wujud keseriusan penyelenggara pendidikan Madrasah Qudsiyyah bagi para siswa-siswanya pada semua tingkatan baik MI, MTs maupun MA sebagai penunjang untuk lebih dalam mempelajari serta memahami pendidikan ilmu agama berbasis salaf di Madrasah Qudsiyyah Kudus. Pembelajaran di Ma'had Qudsiyyah dibagi menjadi dua macam model, yaitu berupa pengkajian mendalam kitab-kitab kuning yang disesuaikan dengan kitabkitab kunig yang diajarkan di madrasah dan berupa pembelajaran konsentrasi bidang tahfidzul qur'an. Dua model pembelajaran tersebut dilaksanakan di Ma'had dengan sistematika setiap hari santri mempelajari kitab-kitab kuning dengan metode bandongan, sorogan dan musyawarah. Adapun yang model pembelajaran tahfidzul qur'an siswa-siswa pada tiap harinya diwajibkan ngaji bin nadzor dan juga setor hafalan minimal 1 ayat setiap hari.

Secara deregulatory MI Qudsiyyah Kudus berkomitmen untuk tetap mempertahankan dan melestarikan pendidikan berbasis kurikulum pesantren tersebut dengan segala pengembangannya tanpa terikat dengan ketentuan pihak lain.

Dalam pengembangannya pihak Madrasah Qudsiyyah secara cooperative menjalin jaringan dengan beberapa pondok pesantren salaf di Jawa Tengah seperti 
Pondok Pesantren Maimuniyyah Kudus sebagai mediator bagi siswa lulusan Madrasah Qudsiyyah yang berminat untuk melanjutkan studi ke timur tengah, Madrasah Qudsiyyah juga menjalin jaringan dengan Pondok Pesantren Al-Anwar Rembang sebagai lembaga yang siap menerima siswa lulusan Madrasah Qudsiyyah untuk mendalami ilmu agama melalui pendidikan salafnya maupun perguruan tingginya.

\section{Pelaksanaan Manajemen Madrasah Unggul Berbasis Kurikulum Pesantren di MI Qudsiyyah Kudus}

Kurikulum yang diajarkan pada madrasah tersebut $75 \%$ berbasis salaf (pesantren) dengan menggunakan kitab klasik atau yang biasa disebut dengan istilah kitab kuning, ada sisi pembeda antara kurikulum berbasis kurikulum pesantren yang ada di MI Qudsiyyah Kudus dengan madrasah lainnya yaitu kitabkitab yang dikaji di MI Qudsiyyah sebagian besar merupakan kitab susunan karya KH. Yahya Arif dan para guru di madrasah tersebut.

Karakteristik pelaksanaan manajemen madrasah unggul mempunyai beberapa dimensi yaitu (Agus Maimun, Agus Zaenul Fitri, 2016:45):

a. Input terseleksi secara ketat. Kepala MI Qudsiyyah dalam mengatur pengembangan kurikulum berbasis kurikulum pesantren telah membentuk tim kerja yang kompeten dan juga solid yang di dalamnya terdiri dari beberapa guru yang mempunyai kompetensi dan berpengalaman dalam hal pengembangan kurikulum.

b. Lingkungan belajar yang kondusif. Kultur lingkungan Madrasah Qudsiyyah semenjak dulu memang sudah bernuansa religius, hal ini dibuktikan dengan banyaknya pondok pesantren di sekitar lingkungan madrasah, peneliti menghitung kurang lebih terdapat 10 pondok pesantren. Ditambah lagi letak madrasah yang berdekatan dengan Komplek Makam Sunan Kudus dan Masjid Menara Kudus sehingga menambah kuatnya nuansa kultur lingkungan yang islami.

c. Guru dan tenaga kependidikannya yang professional. Guru MI Qudsiyyah secara 
keseluruhan merupakan para alumni dari Madrasah Qudsiyyah sendiri yang sudah dipetakan sesuai dengan kualifikasi latar belakang pendidikan untuk selanjutnya ditugaskan sesuai kapasitas kompetensinya

d. Inovasi kurikulum. Terdapat penambahan mata pelajaran muatan lokal salaf pada mata pelajaran muatan lokal dalam kurikulum MI Qudsiyyah. Mata Pelajaran Muatan Lokal Salaf terdiri dari mata pelajaran pesantren yang difungsikan sebagai penguatan dan pendalaman mata pelajaran PAI Kementerian Agama RI. Supaya lebih jelas berikut peneliti sajikan skema fungsi Mata Pelajaran Muatan Lokal Salaf di MI Qudsiyyah Kudus.

e. Kurun waktu belajar lebih lama dibandingkan dengan madrasah lain. Strategi pengembangan kurikulum berbasis pesantren yang diterapkan di MI Qudsiyyah Kudus juga memberlakukan jam tambahan untuk pembelajaran ilmu-ilmu alat (Nahwu dan Shorof) yang diwajibkan bagi siswa kelas atas (Kelas 4 - Kelas 6) yang dilaksanakan setelah jam belajar selesai selama 60 menit. Kemudian untuk pengembangan minat dan bakat siswa, MI Qudsiyyah memberikan wadah melalui berbagai progam ekstrakurikuler. Ada dua jenis Ekstrakurikuler; Ekstrakurikuler yang wajib diikuti siswa yaitu Pramuka dan Ekstrakurikuler pilihan yaitu kegiatan ekstrakurikuler yang dapat dikembangkan dan diselenggarakan dan dapat diikuti oleh peserta didik sesuai bakat dan minatnya masing-masing, meliputi: Kaligrafi, UKS, Rebana, Tilawah, Pencak Silat.

f. Bermanfaat dan berpartisipasi kepada masyarakat. MI Qudsiyyah merupakan lembaga pendidikan yang memberikan pengajaran berbagai mata pelajaran. Baik mata pelajaran umum maupun mata pelajaran agama / salaf pesantren bertujuan sebagai pembekalan kepada semua siswa supaya menjadi pribadi yang berkompetensi kompleks. Sehingga setelah lulus dari MI Qudsiyyah siswa bisa melanjutkan ke jenjang sekolah lanjutan basis agama ataupun umum. Serta dapat mengamalkan ilmunya untuk diri sendiri maupun untuk lingkungan sekitar. 


\section{Evaluasi Manajemen Madrasah Unggul Berbasis Kurikulum Pesantren di MI Qudsiyyah Kudus}

Evaluasi kurikulum memuat lima aspek. (a) Peserta didik, dilakukan dengan mengidentifikasi cara belajar, prestasi belajar, motivasi belajar, keaktifan, kreativitas, hambatan dan kesulitan yang dihadapi. (b) Tenaga pengajar, dengan melakukan pengawasan pada pelaksanaan tanggung jawab, kemampuan kepribadian, kemampuan kemasyarakatan, kemampuan keprofesional, dan loyalitas terhadap atasan. (c) Media pengajaran, dilakukan dengan melihat jenis media yang digunakan, cara penggunaan media, pengadaan media, pemeliharaan dan perawatan media. (d) Prosedur penilaian, dilakukan melalui identifikasi instrumen yang digunakan untuk menilai hasil belajar siswa, pelaksanaan penilaian, dan pelaporan penilaian. (e) Jumlah lulusan, mengidentifikasi lulusan dengan pengelompokan lulusan, jenjang, jenis kelamin, usia, dan kemampuan lulusan (Nur Hamiyah dan Mohammad Jauhar, 2015:16).

MI Qudsiyyah Kudus melaksanakan evaluasi manajemen madrasah berbasis kurikulum pesantren dengan menilai efektifitas progam-progam yang sudah direncanakan di awal perencanaan, serta menelaah hambatan apa saja yang menjadikan progam tersebut tidak bisa terealisasi dengan baik atau bahkan tidak terealisasi sama sekali. Evaluasi dalam pengelolaan madrasah berbasis kurikulum pesantren dilaksanakan dengan dua periodik waktu yang berbeda:

1) Evaluasi proses pembelajaran secara periodik bulanan. Evaluasi ini di MI Qudsiyyah dilaksanakan setiap sebulan sekali, yakni dijadikan satu dengan Rapat Bulanan oleh seluruh guru di MI Qudsiyyah.

2) Evaluasi progam kerja tahunan atau setahun sekali. Evaluasi ini di MI Qudsiyyah dilaksanakan setiap bulan Juni atau Juli bertepatan dengan rapat persiapan tahun pelajaran baru.

Langkah-langkah evaluasi dalam pengelolaan madrasah berbasis kurikulum pesantren di MI Qudsiyyah berdasarkan sudut pandang beberapa informan dalam penelitian ini; 


\section{Sutrisno}

a) Analisis progam yang sudah dicanangkan

Analisis progam dilakukan terlebih dahulu untuk menelaah sisi kekurangan pada progam-progam setelah dilaksanakan. Sehingga dengan hasil telaah tersebut pihak madrasah dapat lebih mudah untuk mendeteksi dan menerapkan solusi yang tepat.

b) Melakukan Pemantauan dan Pengawasan

Pemantauan dan pengawasan dilakukan sebagai upaya untuk mengumpulkan informasi dan data terkait dengan progam-progam yang sudah direncanakan dan sedang dilaksanakan, apakah sudah sesuai dengan perencanaan ataukah belum.

c) Membuat Laporan Tertulis

Tahapan yang terakhir dalam evaluasi ialah membuat pelaporan secara tertulis setiap akhir kegiatan, hal tersebut supaya mempermudah atau dapat menyimpan masalah yang sudah dievaluasi sehingga setiap akhir kegiatan akan ada sebuah catatan-catatan.

Adapun untuk evaluasi progam kerja tahunan dilaksanakan menggunakan evaluasi model CIPP meliputi empat aspek, yaitu: Aspek Konteks, Aspek Input, Aspek Proses dan Aspek Output;

a) Aspek Konteks

Menurut hasil observasi peneliti, konteks latar belakang MI Qudsiyyah meliputi karakteristik lingkungan dan letak geografis ini menjadi suatu dukungan tersendiri bagi terselenggaranya penerapan Pendidikan berbasis kurikulum pesantren di MI Qudsiyyah dikarenakan berada di tengah-tengah kehidupan corak pesantren.

b) Aspek Input

Pada aspek input ini ada tiga macam faktor pendukung untuk pengembangan madrasah berbasis kurikulum pesantren, yaitu: a) keadaan siswa b) keadaan guru dan c) ketersediaan sarana dan prasarana. 
(1) Keadaan siswa

Dikarenakan latar belakang kehidupan siswa dirumah berbeda-beda serta perkembangan menurunnya semangat belajar siswa dikarenakan fokus kepada hal lain maka hal itu sangat mempengaruhi dalam pencapaian tujuan belajar siswa. Maka perlu adanya terobosan atau tawaran solusi baru dalam pengembangan kurikulum kedepannya.

(2) Keadaan Guru

Selain keadaan siswa, aspek input madrasah yang berpengaruh terhadap implementasi kurikulum berbasis pesantren di MI Qudsiyyah adalah keadaan guru. Guru merupakan pihak pertama yang mengendalikan proses pembelajaran. Salah satu upaya yang dilakukan pengurus YAPIQ Kudus adalah perekrutan guru diambilkan dari alumni Madrasah Qudsiyyah sendiri supaya personalia guru mempunyai sikap merasa memiliki dan berorientasi kepedulian mengembangkan madrasah.

(3) Ketersediaan Sarana dan Prasarana

Dalam implementasi Kurikulum Pesantren di MI Qudsiyyah sarana dan prasarana yang dibutuhkan sudah cukup memadai, begitu juga dengan alat peraga praktikum juga sudah ada dan semua dalam keadaan baik.

c) Aspek Proses

Kurikulum yang digunakan di MI Qudsiyyah ini merupakan gabungan antara kurikulum Pembelajaran Agama Islam (PAI) dari Kementerian Agama dengan pembelajaran berbasis kitab-kitab kuning. Kurikulum muatan lokal yang diajarkan di madrasah ini merupakan pelajaran-pelajaran yang biasanya diajarkan di pondok pesantren seperti pelajaran Nahwu, Shorof, I'lal, I'rab, Tauhid, Fiqih salaf, Imla, Tahaji, Tajwid dan Pegon dengan menggunakan metode bandongan dan sorogan. 
d) Aspek Output

Pada aspek ini dapat dilihat dari prestasi akademik yang ditunjukkan dengan lomba karya ilmiah, lomba mata pelajaran dan prestasi non akademik ditunjukkan dengan keingintahuan yang tinggi, kerja sama yang baik, toleransi, kedisiplinan, kerajinan, prestasi olahraga dan seni (Siswanto, 2014:168). Kompetensi peserta didik MI Qudsiyyah relatif unggul diberbagai cabang kompetisi, baik segi aspek akademik maupun aspek non akademik hal ini dapat dibuktikan dengan data dokumentasi inventaris piala kejuaraan lomba siswa MI Qudsiyyah yang banyak menjuarai lomba dalam berbagai event baik tingkat kabupaten maupun provinsi.

\section{Simpulan}

Perencanaan kurikulum berbasis pesantren di MI Qudsiyyah Kudus dilaksanakan oleh seluruh elemen madrasah meliputi kepala madrasah, waka bidang kurikulum, waka bidang sarpras, waka bidang humas, waka bidang kesiswaan, kepala TU dan pengurus komite madrasah. Pokok inti dari proses perencanaan adalah menetapkan point-point penting sebagai dasar rancangan rancangan kurikulum meliputi penelaahan tujuan, konten kurikulum melalui pendekatan mata pelajaran dan pendekatan proses, kegiatan (aktivitas), sumber yang digunakan dan instrumen evaluasi (pengukuran).

Strategi pengembangan manajemen madrasah unggul berbasis kurikulum pesantren meliputi membangun kekuatan internal, memperkuat kepemimpinan, membangun pencitraan madrasah, membuat progam unggulan dan meningkatkan kepedulian sosial dengan empat pendekatan stategi pengembangan; substantif, buttom-up, deregulatory \& cooperative.

Pelaksanaan Manajemen Madrasah Unggul Berbasis Kurikulum Pesantren

di MI Qudsiyyah Kudus berupa kurikulum integrasi antara kurikulum umum dengan kurikulum berbasis salaf (pesantren). 
Evaluasi Manajemen Madrasah Unggul Berbasis Kurikulum Pesantren di MI Qudsiyyah Kudus dilaksanakan dengan dua periodik waktu yang berbeda yaitu evaluasi bulanan dan evaluasi progam kerja tahunan. Langkah-langkah evaluasinya meliputi; Analisis progam yang sudah dicanangkan, Melakukan Pemantauan dan Pengawasan dan Membuat Laporan Tertulis (Aspek Konteks, Aspek Input, Aspek Proses dan Aspek Output).

\section{Daftar Pustaka}

Bafadal, Ibrahim. 2006. Manajemen Peningkatan Mutu Sekolah Dasar, Jakarta: Bumi Aksara.

Djamarah, Syaiful Bahri. 2006. Strategi Belajar Mengajar, Jakarta: PT Rineka Cipta.

Fatmawati, N., Setyowati, D. L., \& Utomo, C. B. (2018). "Outdoor Study Activity by Utilizing Wonosoco Tourism Village as A Learning Resource of Social Studies". Journal of Educational Social Studies, 7 (1): 88-98.

James L Gibson,Terj Djoerban Wahid, 1990. Organisasi dan Manajemen, Perilaku Struktur dan Proses, Jakarta:Erlangga.

Muhaimin, 2009. Rekonstruksi Pendidikan Islam dari Paradigma Pengembangan, Manajemen Kelembagaan, Kurikulum hingga Strategi Pembelajaran, Jakarta: Raja Grafindo Persada.

Nur Hamiyah dan Mohammad Jauhar, 2015. Pengantar Manajemen Pendidikan di Sekolah. Jakarta : Prestasi Pustaka.

Purwanto, M. Ngalim. 2004. Prinsip-Prinsip dan Teknik Evaluasi Pengajaran, Bandung: PT. Remaja Rosdakarya, Cet Ke-12.

Siswanto, 2014. Madrasah Unggulan Berbasis Pesantren, Jurnal Studi Keislaman, STAIN Pamekasan . Vol. 18 Nomor 1.

Soetopo, Hendyat. 2015. Manajemen Pendidikan, Jakarta : Prestasi Pustaka.

Sudjana, Nana. 2008. Pembinaan dan Pengembangan Kurikulum di Sekolah, Bandung: Sinar Baru Algensindo.

Sukirman, Dadang. 2012. Pembelajaran Micro Teaching, Jakarta: Direktorat Jenderal Pendidikan Islam Kementerian Agama RI, Cet. 2.

Umar, Yusuf. 2016. Manajemen Pendidikan Madrasah Bermutu, Bandung: PT. Refika Aditama. 
Yahya, Fata Asyrofi. 2015. Problem Manajemen Pesantren, Sekolah, Madrasah: Problem Mutu dan Kualitas Input-Proses-Output, "Jurnal El-Tarbawi, Vol. VIII No. 1.

Zayadi, Ahmad. 2005. Desain Pengembangan Madrasah, Jakarta: Dirjen Kelembagaan Pendidikan Islam Depag. 